\title{
KONSELING PRANIKAH BERPERSPEKTIF GENDER PADA LEMBAGA (BP4) UNTUK MENURUNKAN TINGKAT PERCERAIAN
}

\author{
Nurhasanah Bakhtiar ${ }^{1}$, Mainizar ${ }^{2}$, Raja Rahima MRA ${ }^{3}$, Hasgimianti $^{4}$ Irawati $^{5}$ \\ Universitas Islam Negeri Sultan Syarif Kasim Riau, Indonesia \\ nurbasanah.bakbtian@uin-suska.ac.id',mainizar.n.05@gmail.com²,raja.rabima.mra@uin- \\ suska.ac.id',hasgimianti@uin-suska.ac.idt,irawati@uin-suska.ac.id
}

\begin{abstract}
The purpose of this research is to explore the implementation of premarital counseling for prospective brides by BP4 Pekanbaru. This research use partisipatory action research approach. The collection of data obtained through observation, interview and documentation. Target objects consists of 14 persons Committee organizers premarital counseling. The collected data were analyzed using descriptive qualitative analysis. Research findings found that implementation of the premarital counseling for prospective brides by BP4 Pekanbaru consists of two programs: first regular program funded by the Ministry of religious affairs of the city of Pekanbaru, the two self-contained programs which cost borne by the participants (the bride). Implementation of premarital counseling for prospective brides by BP4 Pekanbaru yet insightful gender. The materials contained in the premarital guidance manual have not been gender-laden both as a specific subject, or in the explanation. So also in the delivery of materials by the instructor, there is no visible gender charges explicitly.
\end{abstract}

Keywords : Premarital Counseling, Berperspektif, BP4 Gender

\begin{abstract}
ABSTRAK
Tujuan penelitian ini adalah untuk mengeksplorasi pelaksanaan konseling pranikah bagi calon pengantin oleh BP4 Kota Pekanbaru. Penelitian ini menggunakan pendekatan partisipatory action research. Pengumpulan data diperoleh melalui observasi, wawancara dan dokumentasi. Objek sasaran terdiri dari 14 orang panitia penyelenggara konseling pranikah.Data-data yang terkumpul dianalisis dengan menggunakan analisis deskriptif kualitatif. Temuan penelitian didapati bahwa pelaksanaan konseling pranikah bagi calon pengantin oleh BP4 Kota Pekanbaru terdiri dari dua program yaitu pertama program regular yang didanai oleh Kementrian Agama Kota Pekanbaru, kedua program mandiri yang biayanya ditanggung oleh peserta (calon pengantin). Pelaksanaan konseling pranikah bagi calon pengantin oleh BP4 kota Pekanbaru belum berwawasan gender. Materi-materi yang termuat dalam buku panduan bimbingan pranikah belum bermuatan gender baik sebagai satu pokok bahasan khusus, ataupun dalam penjelasan. Begitu juga dalam penyampaian materi oleh instruktur, tidak ada terlihat muatan-muatan gender secara eksplisit.
\end{abstract}

Kata Kunci: Konseling Pranikah, BP4, Berperspektif Gender 


\section{PENDAHULUAN}

Pernikahan merupakan sesuatu yang menjadi sunnatullah dan menjadi salah satu dari ajaran Islam yang disunnahkan oleh Rasulullah SAW. Kehidupan seseorang menjadi lebih terarah, tenang, tenteram dan bahagia jika sudah menikah. Sebagaimana yang terdapat dalam Qur'an surah Ar-Rum: 21 yang menyatakan bahwa tujuan pernikahan adalah agar manusia merasa tenteram dan hidup dengan penuh kasih sayang. Kehidupan yang tentera dalam keluarga tidak serta merta diperoleh oleh pasangan yang menikah. Hidup bersama antara dua individu seringkali muncul ketidakcocokan, karena pada dasarnya setiap individu memiliki cara hidup dan karakter yang berbeda. Karena itu bimbingan sebelum berlangsungnya ikatan pernikahan sangat diperlukan. Adanya bimbingan pranikah sebagai upaya mempersiapkan calon pengantin dalam menempuh kehidupan yang sakinah mawaddah wa rahmah.

Mengingat pentingnya konseling pranikah bagi pasangan yang akan mengharungi bahtera rumah tangga, Kementerian Agama Republik Indonesia melalui Perdirjen Bimas Islam No: PJ.II/542/Tahun 2013 yang dilanjutkan dengan surat dari Badan Penasehat, Pembinaan dan Pelestarian Perkawinan (BP4) Pusat No.059/13-P/BP4/XII/2014 tanggal 16 Desember 2014 mengeluarkan aturan perihal Konseling Pranikah. Menindaklanjuti surat BP 4 Pusat tersebut, maka terhitung mulai dari 1 Mei 2015, bagi masyarakat yang ingin melakukan pendaftaran pernikahannya ke KUA di kota Pekanbaru diwajibkan melampirkan Sertifikat Konseling Pranikah yang dikeluarkan oleh Kementerian Agama. Hal tersebut telah dijelaskan oleh Haryati SE ME, Kasi Penyelenggaraan Syariah Kantor Urusan Agama Kota Pekanbaru, Selasa (17/2/2015) di KUA Pekanbaru. Ketentuan tersebut dituangkan dalam surat Kepala Kantor Kementerian Agama Kota Pekanbaru No Kd. 04.4/07.BA.00/217/2015.

Konseling pranikah adalah pemberian bekal terhadap pengetahuan, pemahaman, keterampilan dan penumbuhan kesadaran kepada remaja usia nikah mengenai kehidupan rumah tangga dan keluarga. (Perdirjen Bimas Islam No: PJ.II/542/Tahun 2013). Konseling tersebut bertujuan untuk meningkatkan kemampuan pengetahuan dan pemahaman tentang kehidupan rumah tangga/keluarga dalam mewujudkan keluarga yang sakinah, mawaddah warahmah serta mengurangi angka perselisihan, perceraian, dan kekerasan dalam rumah tangga. Keluarga sakinah adalah keluarga yang didasarkan atas perkawinan yang telah sah, mampu membina keluarga yang nyaman, damai, tentram dan bahagia serta mampu memenuhi hajat spiritual dan material secara serasi dan 
seimbang, diliputi suasana kasih sayang antara internal keluarga dan lingkungannya, serta mampu memahami, memperdalam, dan mengamalkan nilai-nilai keimanan, ketakwaan dan akhlaqul karimah.(Perdirjen Bimas Islam No: PJ.II/542/Tahun 2013).

Konseling pranikah yang diselenggarakan oleh organisasi profesional yang bersifat sosial keagamaan sebagai bentuk mitra kerja Kementerian Agama dalam mewujudkan suatu keluarga yang sakinah mawaddah warahmah yang disebut dengan BP4 (Badan Penasihatan, Pembinaan dan Pelestarian Perkawinan). Selain itu, dapat juga diselenggarakan oleh organisasi keagamaan Islam yang telah memiliki akreditasi dari Kementerian Agama.

Di Kota Pekanbaru ada dua lembaga resmi yang menyelenggarakan konseling pranikah, yaitu pertama BP4 Kota Pekanbaru sebagai mitra Kementerian Agama Kota Pekanbaru. Kedua, Lembaga Penyuluhan dan pendidikan Keluarga Sakinah (LP2KS) Fakultas Syariah dan Ilmu Hukum Universitas Islam Negeri Sultan Syarif Kasim Riau. Lembaga ini merupakan suatu organisasi yang bersifat profesi yang bertujuan sebagai penunjang tugas Kementerian Agama dalam bidang penasehatan pernikahan dan pembinaan keluarga bahagia dan sejahtera, serta bertujuan untuk meningkatkan mutu pernikahan dan mewujudkan keluarga yang bahagia, sejahtera dan kekal menurut Islam.

Pelaksanaan konseling pranikah sejak 2015 sampai saat ini belum memperlihatkan hasil yang maksimal dalam mencegah angka perceraian. Bisnis.com, PEKANBARU Kakanwil Kementerian Agama Riau mengungkapkan, bahwa data yang diperoleh dari Pengadilan Agama menyebutkan bahwa angka perceraian pada tahun 2016 mencapai hingga 30 persen dari total pernikahan yang terjadi."Untuk tahun 2016 angka perceraian mencapai hingga 30 persen dari angka pernikahan, dan rata-rata angka pernikahan sekitar 48.000 per tahun," ujar Kakanwil Kemenag Provinsi Riau Ahmad Supardi di Pekanbaru, Senin $(23 / 1 / 2017)$.

Di penghujung tahun 2017, tercatat 1.462 kasus perceraian yang terjadi di Kota Pekanbaru. (Conesia Com 19-10-2017). Berdasarkan keterangan dari Panitera Hukum Pengadilan Agama Pekanbaru, kasus perceraian yang telah terjadi di Pekanbaru cukup tinggi. Dari 1.462 kasus perceraian, sebagian besar adalah kasus gugat cerai yang telah diajukan oleh pihak perempuan. Angka ini mendekati jumlah kasus perceraian yang telah terjadi pada tahun 2016 sebanyak 1.700 kasus. Salah seorang pegawai Pengadilan Agama Kota di Pekanbaru mengatakan bahwa pada umumnya gugatan perceraian yang telah masuk ke Pengadilan Agama di Kota Pekanbaru disebabkan oleh masalah ekonomi, perselingkuhan dan tidak adanya kecocokan antar pasangan. (www. Riau.go.id, 11 Juni 
2015). Panitera Muda Hukum PA Klas I A Pekanbaru, Fakhriadi Senin (15/1/18) menyebutkan bahwa sisa kasus gugat cerai yang belum disidangkan pada 2016 sebanyak 278 kasus ditambah jumlah pengajuan gugat cerai sepanjang 2017 sebanyak 1956 kasus. Jika diakumulasikan, kasus gugat cerai di PA Klas IA Pekanbaru selama 2017 sebanyak 2.234 kasus. Menurutnya, kebanyakan pasangan yang telah mengajukan gugatan cerai kepada pasangannya itu berakar dari pertengakaran, perselisihan, sudah tidak adanya kecocokan antar pasangan hingga permasalahan ekonomi dalam rumah tangga.(Riausky.com, 15 Januari 2018).

Tingginya kasus perceraian yang telah terjadi di Kota Pekanbaru, menggambarkan kegagalan pasangan suami istri untuk menjalani bahtera rumah tangganya. Hal ini tentu disebabkan oleh ketidaksiapan pasangan dalam menjalankan fungsi, tugas dan perannya secara baik dan berimbang. Pasangan yang akan menikah tidak dibekali ilmu yang cukup tentang prihal berumah tangga, terutama dalam menjalankan peran dan relasi antar pasangan. Pemahaman yang cukup tentang relasi antar pasangan akan lebih kuat jika materi konseling juga dilihat dari persfektif gender. Hal ini penting karena seringkali persfektif figh klasik menimbulkan pemahaman yang bias gender sehingga berdampak pada ketidakadilan dan ketidak harmonisan dalam rumah tangga. Ditambah lagi kontruksi budaya dalam masyarakat dimana adanya superioritas laki-laki atas perempuan, mengakibatkan perempuan mendapat perlakuan yang tidak adil.

Bimbingan pranikah dalam persfektif gender penting dilakukan agar antara suami dan istri dapat memahami karakter dan perbedaan satu dengan lainnya, sehingga terwujud keadilan gender.(Lilis Widaningsih: 2017). Berkeadilan gender bukan berarti mendapat porsi yang sama banyak. Suami dan istri melakukan tugas dan kewajibannya dalam hubungan yang saling memahami, menyayangi, membantu, mengisi dan mengasihi satu sama lain.

\section{METODOLOGI PENELITIAN}

Kegiatan pengabdian kepada masyarakat ini dilakukan menggunakan metode partisipatory action research (PAR) (Cornwall, A., \& Jewkes, R :1995). Dalam penelitian ini peniliti terlibat aktif dalam kegiatan bimbingan dan konseling pranikah yang diadakan oleh BP4 Kota Pekanbaru. Data diperoleh dengan cara observasi, wawancara dan dokumentasi. Observasi dilakukan terhadap kegiatan bimbingan konseling pranikah yang dibimbing oleh instruktur BP4. Selanjutnya mewawancarai ketua dan beberapa instruktur BP4 Kota 
Pekanbaru serta beberapa orang calon pengantin sebagai peserta bimbingan calon pengantin. Selain observasi dan wawancara, dokumentasi BP4 seperti brosur, buku panduan dan modul bimbingan konseling pranikah menjadi sumber data dalam penelitian ini.

\section{TEMUAN DAN DISKUSI}

Berdasarkan hasil observasi, program bimbingan konseling pranikah yang dilaksanakan oleh Badan Penasehat Pembinaan dan Pelestarian Perkawinan (BP4) Kota Pekanbaru terdiri dari dua bentuk program. Pertama program konseling pranikah reguler yang masuk dalam anggaran Kementerian Agama Kota Pekanbaru. Kedua, program konseling pranikah secara mandiri yang pembiayaannya dibebankan kepada peserta. Program reguler dilaksanakan pada hari Selasa dan Rabu dari pukul 8.00 - 17.00 WIB. Program mandiri dilaksanakan pada hari Sabtu dan Ahad pukul 8.00 sampai 14.30 WIB. Peserta program reguler terdiri dari 60 orang ( 30 pasang catin), sedangkan peserta program mandiri diikuti oleh 100 orang ( 50 pasang catin).

Kedua program sama-sama dilaksanakan di kompleks perkantoran Mesjid ArRahman Kota pekanbaru. Kompleks perkantoran Masjid Ar-Rahman sendiri dipersiapkan untuk dapat menampung pasangan akan menikah dengan fasilitas yang cukup baik. Di ruangan pelatihan disediakan slide show, sound system, papan tulis, white board, dan media visual yang menunjang konseling pranikah bagi calon pasangan pengantin. Kedua program diadakan di ruagan yang berbeda.

Pelaksanaan konseling pranikah diatur dalam Peraturan Direktorat Jenderal Bimbingan Masyarakat Islam (Dirjen Binmas Islam) Nomor DJ.II/491 Tahun 2009 tanggal 10 Desember 2009 Tentang Kursus Calon Pengantin (Suscatin) dijelaskan bahwa Kursus Calon Pengantin (Suscatin) dalam konteks ini dirumuskan sebagai upaya memberikan bekal pengetahuan, pemahaman dan keterampilan dalam waktu singkat kepada calon pengantin tentang kehidupan rumah tangga/keluarga laki-laki muslim dan perempuan muslimah yang akan menjalani kehidupan rumah tangga dalam suatu ikatan pernikahan. Adapun alokasi waktu yang diperlukan dalam pelaksanaan Kursus Calon Pengantin (Suscatin) adalah dengan alokasi waktu 24 jam pembelajaran (https://pekanbaru. kemenag.go.id/sejarahsingkat/BP4)_dengan rincian sebagai berikut : (1) Tata cara dan prosedur perkawinan selama 2 jam. (2) Pengetahuan agama selama 5 jam. (3) Peraturan perundangan di bidang perkawinan dan keluarga selama 4 jam. (4) Hak dan kewajiban suami istri selama 5 jam. (5) 
Kesehatan reproduksi selama 3 jam. (6) Manajemen keluarga selama 3 jam, dan; (7) Psikologi perkawinan dan keluarga selama 2 jam.

Pelaksana atau instruktur konseling pranikah untuk kedua jenis progam tersebut juga berbeda. Untuk konseling pranikah reguler diberikan oleh instruktur yang sudah mengikuti training dan bersertifikat, yaitu Ibu Haeryati, SE, ME,Sy.Ak dan Bapak Masrizal. Sedangkan untuk program mandiri diberikan oleh instruktur yang diambil dari beberapa orang kepala KUA di Kota Pekanbaru seperti H. AN Khofifi, M.H dan lainnya.

Terdapat perbedaan antara cara penyampaian materi dari kedua program BP4 ini, untuk program reguler, pemateri lebih interaktif dan menggunakan banyak media serta strategi (Problem solving dan Role Playing). Dengan demikian peserta lebih aktif dan tercipta suasana hangat. Sedangkan untuk program mandiri, pemateri lebih banyak memberikan ceramah dan tidak terlalu banyak mengajak peserta untuk berdiskusi. Suasana di dalam ruangan tempat kegiatan pun menjadi berbeda, untuk program mandiri, karena jumlah yang cukup banyak, maka tidak terlalu kondusif dan sulit untuk membuat strategi bimbingan yang bervariatif. Namun, kedua program sama-sama memberikan materi yang sangat dibutuhkan oleh calon pengantin.

Materi yang disampaikan dalam konseling pranikah untuk kedua program BP4 tersebut di atas tidak berbeda secara substansi. Namun berbeda dari segi pengembangan materi dan cara penyampaian. untuk panduan, kedua program BP4 tersebut di atas menggunakan buku yang sama yaitu Fondasi Keluarga Sakinah (Bacaan Mandiri Calon Pengantin) terbitan Subdit Bina Keluarga Sakinah Direktorat KUA dan Keluarga Sakinah Ditjen Islam Kemenag Republik Indonesia.

Dari kedua program konseling pranikah yang diselenggarakan oleh BP4 Kota Pekanbaru, terlihat bahwa program reguler lebih baik dari program mandiri. Hal ini terlihat dari pegiawaian para instruktur dalam menyampaikan materi secara komunikatif dan metode yang bervariasi. Jumlah peserta yang lebih sedikit memungkinkan mengembangkan metode untuk mengaktifkan peserta dalam kegiatan dan menemukan solusi-solusi dari berbagai masalah yang mungkin timbul dalam kehidupan berkeluarga. Dengan demikian peserta terlihat aktif, bersemangat dan antusias dalam mengikuti kegiatan. Alokasi waktu yang lebih banyak menjadi pendukung tersampaikannya materi secara maksiamal.

Pelaksanaan bimbingan pranikah yang sudah dilakukan di BP4 Kota Pekanbaru, pada dasarnya sesuai dengan tujuan diadakannya konseling pranikah (Brememer dan Shostrom: 2013) adalah sebagai berikut (1) Membantu klien untuk mencapai pemahaman 
lebih baik tentang dirinya, sehingga masing-masing pasangan dan tuntutan pernikahaan serta agar individu mempunyai persiapa-persiapan yang lebih matang dalam kehidupan rumah tangga, (2) Meningkatkan kondisi-kondisi yang lebih baik bagi penyesuaian keluarga sehingga keluarga tersebut mendapatkan kesejahteraan dan kebahagiaan serta dapat meningkatkan kesadaran tentang kekuatan dan potensinya terhhadap masing-masing individu dan (3) Menggembangkan komunikasi yang baik dalam meyelesaikan dan mengelola persoalan-persoalan yang dihadapi dengan sebaik-baiknya sehingga memperoleh kebahagiaan.

\section{Perspektif Gender dalam Konseling Pranikah di BP4 Kota Pekanbaru}

Kajian tentang gender seyogyanya diberikan untuk memahamkan pasangan calon pengantin mengenai tugas, peran dan fungsi masing-masing dalam pernikahan. Dalam materi yang disampaikan oleh instruktur suscatin (kursus calon pengantin) tidak menyentuh persoalan gender secara eksplisit. Secara implisit, kesetaraan gender disampaikan dalam bentuk materi tugas suami istri dalam rumah tangga saja. Begitupun dalam modul yang dipegang oleh instruktur, tidak tergambar kajian tentang kesetaraan gender.

Modul yang dipegang oleh instruktur (Fondasi Keluarga Sakinah (Bacaan Mandiri Calon Pengantin) memiliki 10 bab kajian. Berikut 10 bab dalam modul suscatin BP4 Kota Pekanbaru: (1) Membangun Landasan Keluarga Sakinah. (2) Merencanakan Perkawinan yang Kokoh Menuju Kelurga Sakinah. (3) Dinamika Perkawinan. (4) Kebutuhan Keluarga. (5) Kesehatan Keluarga. (6) Generasi Berkualitas. (7) Ketahanan Keluarga dalam Menghadapi Tantangan Kekinian. (8) Mengenali dan Menggunakan Hukum untuk Melindungi Perkawinan dan Keluarga. (9) Mengelola Konflik Keluarga (10) Prosedur Pendaftaran dan Pencatatan Peristiwa Nikah atau Rujuk.

Berdasarkan analisis peneliti terhadap buku panduan yang digunakan oleh BP4 Kota Pekanbaru, tidak ada bab yang khusus membahas tentang kesetaraan gender dalam rumah tangga. Meskipun dalam bab tersebut membahas dan menyebut kata suami dan istri namun tidak tergambar konsep tentang kesetaraan gender, melainkan dibahas secara umum. Berdasarkan hasil wawancara peneiti dengan penyelenggara dan instruktur bimbingan pranikah, tergambar bahwa pemahaman konsep gender masih sangat kurang. Dari 6 instruktur yang diwawancarai, hanya satu orang yang memahami konsep gender. Konsep gender yang dipahami itupun tidak dituangkan dalam penyampaian materi bimbingan pranikah. 
Secara umum, konsep gender belum tersosialisasi dengan baik di Kementerian Agama khsusnya di Kota Pekanbaru. Ketika ada undangan untuk kegiatan yang berperspektif gender, utusan yang mengahdiri kegitan tersebut selalu ditugaskan kepada perempuan, sekalipun yang diundang adalah kepala Kantor Kementerian Agama Kota Pekanbaru. (Wawancara dengan salah seorang instruktur tgl 11 September 2018).

Berdasarkan uraian di atas, perlunya para instruktur memahami konsep gender secara baik dan utuh, agar mereka dalam memberikan materi yang berspektif gender. Konsep ini perlu disampaikan agar masing-masing (suami-istri) bisa saling bekerjasama dan saling membantu dalam melaksanakan urusan rumah tangga. Tidak ada kaplingan yang secara mutlak antara tugas suami atau istri. Keduanya bisa saling bekerjasama dan mengisi kekuarangan satu sama lain.

Kesetaraan gender, dikenal juga sebagai keadilan gender, adalah pandangan bahwa semua orang harus menerima perlakuan yang setara dan tidak didiskriminasi berdasarkan identitas gender mereka. Gender dimaknakan sebagai suatu bentuk konsep kultural yang berupaya dalam membuat pembedaan (distinction) dalam hal perilaku, peran, metalitas serta karakteristik emosional antara laki-laki dan perempuan yang berkembang dalam masyarakat pada umumnya (Tierney.1989). menurut Fakih, (2005) bahwa gender adalah sifat yang te;ah melekat pada diri seorang laki-laki maupun perempuan yang dikonstruksi secara sosial maupun kultural dan dapat dipertukarkan, artinya adanya perbedaan fungsi, peran dan tanggung jawab antara seorang laki-laki maupun perempuan sebagai hasil konstruksi sosial.

Membahas permasalahan gender berarti membahas permasalahan perempuan dan juga laki-laki dalam kehidupan masyarakat. Pengertian gender menurut Caplan (1987) adalah perbedaan perilaku antara seorang laki-laki dan perempuan selain dari struktur biologis, sebagain besar justru terbentuk melalui proses cultural dan sosial. Definisi yang lain disebutkan oleh Bem (1981) bahwa gender adalah salah satu karakteristik kepribadian seseorang baik laki-laki maupun perempuan yang dapat dipengaruhi oleh peran gender yang telah dimilikinya dan dapat dikelompokkan menjadi 4 klasifikasi yaitu maskulim, feminism, androgini dan tak tergolongkan. Maskulin diartikan sifat kelaki-lakian diatas rata-rata, sifat kurang dari rata-rata. Ciri-ciri yang berkaitan atau sesuai dengan gender ini yang lebih umumnya terdapat pada seorang laki-laki, atau suatu peran atau trait maskulin yang telah dibentuk oleh budaya. Sehingga sifat ini dipercaya adalah sifat bagi laki-laki. Tipe feminism merupakan sifat kewanitaan di atas rata-rata sifat kelaki-lakiannya kurang dari rata-rata. Ciri atau sifat yang umum terdapat pada wanita dan merupakan sifat ideal bagi wanita. 
Sedangkan tipe androgini adalah sifat kelaki-lakian maupun kewanitaanya di atas rata-rata. Terakhir adalah tipe tidak tergolongkan yakni sifat kelaki-lakiannya maupun kewanitaannya di bawah rata-rata. Tingginya kehadiran karakteristik maskulin dan feminism yang diinginkan pada satu individu pada saat yang bersamaan (Snatrock, 2003).

Pandangan terhadap gender ini dapat diklasifikasikan yang pertama yaitu, kedalam dua model yaitu equity model dan complementary contribution model, kemudian yang kedua yaitu kedalam dua stereotype yaitu sex role stereotypes dan managerial stereotypes. Model pertama mengasumsikan bahwa antara seorang laki-laki dan wanita sebagai professional adalah identic sehingga diperlukannya suatu cara yang sama dalam hal mengelola dan wanita harus diuraikan dalam suatu akses yang sama tanpa adanya perbedaan. Model kedua berasumsi bahwa seorang laki-laki dan wanita harus dapat mengelola dan tahu menganai cara menilai, mencatat serta mengkombinasikan sesuatu sehingga dapat menghasilkan suatu sinergi (Trisnaningsih, 2002).

Pandangan lain yang dikemukan oleh Oakley (1972) menyebutkan bahwa gender merupakan suatu perbedaan jenis kelamin yang tidak termasuk biologis dan bukan kodrat dari Tuhan. Sedangkan menurut Zainuddin, (2006) gender yaitu sebagai suatu pola relasi pada lelaki dan perempuan berdasarkan pada ciri sosial masing-masing. Makna yang sama juga dikemukan oleh Eviota, (1992) bahwa gender adalah konstruksi dan tatanan sosial mengenai berbagai perbedaan antar jenis kelamin yang mengacu kepada relasi-relasi sosial anatara perempuan dan laki-laki atau suatu sifat yang telah ditetapkan secara sosial maupun budaya.

Menurut Unger \& Crawford (1992) menyatakan gender merupakan perbedaan antara perempuan dan laki-laki yang dikonstruksi secara sosial bukan berdasarkan perbedaan biologis semata. Hal yang sama dikemukakan oleh Moser (1993) gender merupakan suatu peran sosial yang terbentuk didalam masyarakat. Perbedaan peran dalam gender ini berasal atau terbentuk karena adanya faktor-faktor ideologis, etnis, sejarah, ekonomi dan kebudayaan. Gender merupakan bentuk perbedaan perilaku antara seorang laki-laki dan perempuan bukan terbentuk secara biologis, melainkan terbentuk melalui suatu proses kultural dan sosial. Gender ini dapat berubah-ubah sedangkan jenis kelamin biologis akan tetap tidak akan berubah (Grewal \& Kaplan, 2002).

Sedangkan Mosse (1996) menyebutkan bahwa gender adalah seperangkat peran yang diberikan kepada seorang laki-laki dan perempuan, bukan terbentuk secara biologis namun peran ini dapat berubah sesuai dengan usia, budaya, kelas sosial maupun latar 
belakang etnis. Gender dapat menentukan berbagai suatu pengalaman hidup dan mampu menentukan suatu akses dalam hal alat-alat, pendidikan, kerja, maupun sumber daya. Gender ini dapat berkaitan dengan relasi dan kualitas yang dapat terbentuk didalam suatu hubungan kekuasaan dan dominasi dalam bentuk struktur kesempatan hidup seorang lakilaki maupun perempuan, serta pembagian kerja yang lebih luas yang pada gilirannya berakar pada suatu kondisi produksi dan reproduksi yang diperkuat oleh suatu system ideology, agama dan budaya yang telah berlaku didalam masyarakat (Ostergaard, 1992). Hal lain dikemukan oleh Bradley (2007) bahwa gender merupakan suatu konstruksi sosial yang mengkategorikan laki-laki dan perempuan berdasarkan pada persepsi dan perasaan. Gender ini bervariasi dapat berdasarkan tempat, waktu, budaya dan pengalaman hidup.

Berdasarkan pengertian diatas dapat disimpulkan bahwa gender itu dapat dipahami sebagai suatu konsep yang digunakan dalam mengidentifikasi perbedaan antara seorang laki-laki dan perempuan yang dilihat dari segi pengaruh agama, sosial dan budaya serta arti dalam gender adalah suatu bentuk yang direkayasa oleh masyarakat, bukan sesuatu yang telah bersifat kodrati.

Kesetaraan gender berarti kesamaan suatu kondisi bagi seorang laki-laki maupun perempuan dalam memperoleh suatu kesempatan serta hak-haknya sebagai manusia, agar dapat berperan dan berpartisipasi dalam berbagai kegiatan seperti kegiatan hukum, politik, ekonomi dan sosial budaya, pendidikan serta pertahanan dan keamanan nasional, serta kesamaan dalam hal menikmati hasil pembangunan tersebut. Kesetaraan gender juga dapat meliputi suatu penghapusan diskriminasi dan ketidakadilan struktural, baik terhadap seorang laki-laki maupun perempuan. Sebagai contoh dalam kehidupan berkeluarga perlu dijelaskan makna kepala rumah tangga, manakala sang suami telah meninggal maka istri dapat dikatakan kepala rumah tangga bagi anak-anaknya. Contoh lain adalah mencari nafkah, jika sang suami tidak bekerja maka istri yang memiliki pekerjaan tetap dapat mengambil alih sebagai pencari nafkah, namun begitu kepala keluarga tetap sang suami. Dalam kesetaraan gender, laki-laki dan perempuan akan diberi pemahaman tentang fungsi gender dengan adil dan mereka tidak lagi mendapat tekanan dikarenakan budaya yang seakan-akan memiliki paham yang tidak fleksibel terhadap tugas dalam pengelolaan rumah tangga. Ketidakpahaman terhadap kesetaraan gender seringkali menjadi pemicu perceraian.

Kasus perceraian yang marak terjadi di masyarakat tidak hanya karena budaya yang menekan kesetaraan gender. Faktor lain adalah ketidak pedulian masyarakat itu sendiri. Apabila berbicara tentang gender maka banyak orang berpikir perempuan ingin mengambil 
alih tugas laki-laki dan sebaliknya, namun sebenarnya kesetaraan gender tidak menginginkan beban ganda (double burden) bagi istri (perempuan) dan suami (laki-laki). Pemahaman mengenai suatu subyek-obyek, superior-imperior, dominan-tidak dominan serta pembagian peran-peran yang tidak sesuai atau tidak seimbang antara anggota keluarga laki-laki (ayah, anak laki-laki) maupun anggota keluarga perempuan (ibu, anak perempuan) (Syaiful Anwar, 2016:199). Sehingga materi tentang kesetaraan gender sangat penting mengingat tujuan dari pelaksanaan BP4 adalah : (1) Memberikan suatu nasehat serta penerangan mengenai hal-hal seperti nikah, talak, cerai, dan rujuk terhadap yang akan melakukannya baik itu secara perorangan maupun dalam bentuk kelompok. (2) Mencegah agar tidak terjadi suatu perceraian (cerai talak ataupun cerai gugat), poligami yang tidak bertanggung jawab, sewenang-wenang, perkawinan di bawah tangan dan perkawianan di bawah umur. (3) Memberikan suatu bantuan terkait dalam hal mengatasi suatu permasalahan seperti masalah perkawinan, keluarga dan perselisihan dalam rumah tangga.

(4) Memberikan suatu bimbingan serta penyuluhan terhadap undang-undang perkawinan dan hukum munakahat. (5) Bekerjasama dengan lembaga, instansi, dan organisasi yang memiliki suatu kesamaan yang bertujuan baik di dalam maupun di luar negeri. (6) Menerbitkan berbagai sumber media cetak seperti majalah, buku, brosur, dan penerbitan lain. (7) Menyelenggarakan adanya kursus, diskusi, penataran, seminar dan kegiatan yang sejenisnya. (8) Meningkatkan suatu penghayatan serta pengamalan ajaran islam dalam hal rangka membina keluarga (rumah tangga) sehat, bahagia serta sejahtera. (9) Meningkatkan pelaksanaan pedoman penghayatan dan pengamalan pancasila (P4) dalam keluarga. (10) Berperan serta aktif dalam kegiatan lintas sektoral yang bertujuan membina keluarga (rumah tangga) sehat, bahagia dan sejahtera. (11) Usaha lain yang dipandang bermanfaat bagi kebahagiaan dan kesejahteraan keluarga (rumah tangga) (https://pekanbaru.kemenag.go.id/sejarah-singkat/BP4).

Urgensi pelaksanaan konseling pranikah bagi para calon pengantin seperti yang dikemukaka oleh Abdul Basit (2016) bahwa Masalah-masalah yang ada pada rumah tangga yang disebabkan oleh perkawinan, seperti perselingkuhan, kekerasan dalam rumah tangga, konflik antar anggota keluarga dan terjadinya perceraian yang merupakan fenomena nyata yang suda ada di dalam masyarakat. Sehingga untuk membantu mengatasi masalahmasalahn yang terjadi di dalam rumah tangga tersebut, diperlukannya pengadaan bimbingan konseling perkawinan. 
Tujuan dari BP4 melaksanakan konseling pranikah atau suscatin akan semakin baik apabila instruktur memahami betul makna kesetaraan gender. Dengan pemahaman yang baik tentang kesetaraan gender, maka materi yang diberikan dapat diarahkan agar calon pasangan pengantin memahami tugas dan fungsi mereka dalam rumah tangga berdasarkan perspektif gender tersebut. Harapan dari pelaksanaan konseling pranikah bagi calon pasangan pengantin berwawasan gender adalah mereka dapat membangun keluarga yang sakinah dan terhindar dari perceraian.

Relasi antara suami dan istri dalam keluarga merupakan hubungan yang saling membutuhkan dan tidak terpisahkan. Murata (1996) mengibaratakan relasi laki-laki dan perempuan seperti hubungan langit dan bumi, berpasangan, saling membutuhkan. Masingmasing memiliki kelebihan untuk diberikan kepada pasangannya. Sebaliknya memiliki kekurangan yang mesti diisi oleh pasangannya. Atika (2017) menyatakan bahwa salah satu kelebihan perempuan adalah dengan diberi rahim, yang dengan rahim tersebut kecenderungan laki-laki menyayangi perempuan dan tempat persemaian cinta antara keduanya.

Menurut Syaiful Anwar (2016), pemahaman tentang perbedaan biologis, aspirasi, kebutuhan, kemampuan yang ada pada masing-masing anggota keluarga sebaiknya dapat ditanamkan sejak awal terbentuknya sebuah keluarga. Sistem patriarkat yang meletakkan posisi fungsi-fungsi yang ada dalam keluarga harus berdasarkan pada bentuk struktur yang kaku dan memiliki hierarki kekuasaan yang membatasi adanya peran-peran partisipatif antar anggota keluarga yang telah menyebabkan terjadinya ketidaksesuaian, ketimpangan dan ketidakadilan. Relasi gender yang ada dalam keluarga dapat dibentuk dan juga dibangun jika masing-masing individu dapat saling memahami perbedaan serta kebutuhan yang dimiliki masing-masing individu tersebut serta mampu memberikan suatu kesempatan pada masingmasing individu agar dapat seimbang tanpa membeda-bedakan peran gender.

Kesetaran gender dalam keluarga termasuk juga dalam memperlakukan anak dan mendidik anak. Evi Fatimatur Rusydiyah (2016) menyebutkan bahwa keadilan setiap orang tua terhadap anaknya dalam hal memberikan pendidikan karena itu dapat menjadi fondasi dasar dalam penerapan kesetaraan gender. Demikianpula dalam bidang pendidikan, setiap anak berhak untuk memperoleh atau mendapatkan pendidikan yang layak dan sama dalam sebuah keluarga dan lingkungan masyarakat. 


\section{KESIMPULAN}

Kegiatan bimbingan pranikah bagi calon pengantin oleh BP4 Kota Pekanbaru merupakan kegiatan yang sangat positif dan perlu diikuti oleh pasangan yang akan menikah. Pelaksanaan bimbingan pranikah yang sudah terlaksana dengan baik khususnya pada program reguler. Kaunggulan program reguler terlihat pada kemampuan instruktrur dalam penguasaan, pengembangan dan penyampaian materi dengan berbagai metode yang bervariasi, sehingga peserta lebih antusias dan bersemangat dalam mengikuti kegiatan. Namun ada sisi yang kurang dan perlu disempurnakan dalam penyampaian materi dengan menambah pokok bahasan " Membangun relasi gender dalam keluarga”. Hal ini penting untuk memberikan pemahaman kepada calon pengantin untuk membina dan melestarikan pernikahan untuk mewujudkan rumah tangga yang sakinah mawaddah wa rahmah.

\section{DAFTAR PUSTAKA}

Abdul Basit, “ Koseling Perkawinan dalam Perspektif al-Qur'an”, Konseling Religi: Jurnal Bimbingan dan Konseling Islam, Vol. 7 Desember 2016, h. 175 - 194.

Atika Zuhratus Sofiyah, “ Relasi Gender dalam Kajia Islam he Tao of Islam Karya Sachito Murata" Jurnal Tadrib, Vol III No 1 Juni 2017, h. 119-142.

Bem, S.L. 1981. Gender Schema Theory: A Cognitive Account of Sex Typing. Psychological Review. 88, 354-364.

Boozer, M., Ranis, G., Stewart, F., \& Suri, T. (2003). Paths to Success: The Relationship Between Human Development and Economic Growth. Center Discussion Paper No. 874 Economic Growth Center Yale University, 1-49.

Caplan, P. 1987. Cultural Construction of Sexuality. London: Tavistock Publication.

Cornwall, A., \& Jewkes, R. (1995). What is participatory research? Social Science \& Medicine, 41(12): 1667-1676.

Evi Fatimatur Rusydiyah. 2016. “ Pendidikan Islam dan Kesetaraan Gender: Konsepsi Sosial tentang Berkeadilan Pendidikan dan Keluarga" Jurnal Pendidikan Agama Islam, Volume 4 No 1 Mei 2016, h. 22-43. 
Eviota, Elizabeth. 1992. The Political Economy of Gender. London: Zed Books, Ltd.

Greenwood, D. J., Whyte, W. F., \& Harkavy, I. (1993). Participatory Action Research as a Process and as a Goal. Human Relations, 46 (2), 175.

Lilis Widaningsih. 2017. “ Relasi Gender dalam Keluarga: Internalisasi Nilai-nilai Kesetaraan dalam Memperkuat Fungsi Keluarga" Tim Pokja Gender Bidang Pendidikan Dinas Pendidikan Provinsi Jawa Barat.

Mansour Fakih. 2004. Gender dan Analisis Transformatif. Pustaka belajar: Yokyakarta.

Mohd. Anuar Ramli. 2012. “Analisis Gender dalam Hukum Islam” dalam Jurnal Fiqh, No. 9 (2012) 137-162.

Moser, C.O.N. 1993. Gender Planning and Development Theory. Practice and Training. New York: Roudledge.

Moser, Caroline O. N. (1993). Gender Planning and Development: Theory, Practice, and Training. London: Routledge

Mosse, Y.C. 1996. Gender dan Pembangunan. Terj. Hartian Silawati. Yokyakarta: Rifka Annisa Women's Crisis Center dan Pustaka Pelajar Ofset.

Murata, Sachiko. Kitab Rujukan tentang Relasi Gender dalam Kosmologi dan Teologi Islam. Diterjemahkan dari The Tao of Islam: A. Source book on Gender Relationship in Islamic Thought, Penerjemah Rahmani Astuti dan M.S. Nasrullah. (Bandung: Mizan). 1996.

Oakley, Aan. 1972. Sex, Gender and Sociaty. New York: Yale University.

Santrock. 2003. Adolesence Perkembangan Remaja. Jakarta: Erlangga.

Sarifa Suhra. 2016. "Kesetaraan Gender dalam Persfektif al-Qur'an dan Implikasinya Terhadap Hukum Islam” Jurnal al-Ulum, Volume 13 Nomor 2 Desember 2013, h. 373-394.

Syaiful Anwar. 2016. "Urgensi Pendidikan Gender dalam keluarga" Terampil: Jurnal Pendidikan dan Pembelajaran Dasar, Volume 3 Nomor 2, 2016, h. 199-217.

Tierney, Helen. (ed.) Women's studies encyclopedia, Vol.1. Views from the sciences. New York, London: Greenwood, 1989.

Trisnaningsih. 2004. "Perbedaan Kinerja Auditor dilihat dari Segi Gender" Jurnal Riset Akutansi Indonesia. Vol 7 Nomor 1 Januari 2004. H. 108-123.

Unger \& Crawford.1992. Wome and Gender: A Feminist Psychology. USA: McGraw- Hill. 
Zainuddin Maliki. 2006. Bias gender dalam Pendidikan Sosiologi. Jakarta.

Peraturan Dirjen Bimas Islam No: PJ.II/542/Tahun 2013.

Hasan Afriadi, Kompasiana .com/berita/ Kasus Perceraian di Pekanbaru/ Kamis 19-102017. 